\title{
Sense of Place to Campus amongst Undergraduate Students in USM
}

\author{
Qingjiu Sun \\ School of Housing, Building and Planning, University Sains Malaysia, Pulau Penang, Penang, Malaysia \\ College of Architecture and Civil Engineering, Hebei University, Baoding, Hebei, China \\ Nor Zarifah Binti Maliki \\ School of Housing, Building and Planning, University Sains Malaysia, Pulau Penang, Penang, Malaysia
}

\begin{abstract}
Campus life is very important for the undergraduate students during their experience. This study explores the undergraduate students-campus relationship in University Sains Malaysia (USM). Using questionnaire survey to 114 respondents and applying SPSS to analyze, the students' sense of place to campus with three constructs of place dependence, place attachment and place identity is presented. The international and local students' place identity varied significantly while their place dependence and place attachment showed no significant difference. The students' sense of place in the three constructs varied significantly by different races. Based on the results in this study and relative literature, this paper proposes that place identity may represent a higher hierarchy of people - place relationship than place dependence and place attachment.
\end{abstract}

KEYWORD: Sense of place; Campus; Place dependence; Place attachment; Place identity

\section{INTRODUCTION}

Place is important to people's daily life because it is the center of "felt value where biological needs, such as those for food, water, rest, and procreation, are satisfied" (Tuan, 1974, p. 4). People have become bonded to their places for the places can meet their basic drives for security, belonging and rootedness when they create a deep experiential and emotional connection to the place. Some places play a large role throughout individual life, such as home, neighborhood, the city where you live, as well as university campus where you spent the youth time.

Universities are not only institutions for academic leaning, but also sites of collective section of memories and place meaning. Although there are numerous previous studies that explore the students' performance on campus in terms of dormitory satisfaction (Amole, 2009; Khozaei, Hassan, \& Khozaei, 2010), first-year students' transition from home to university (Chow \& Healey, 2008; Lowe \& Cook, 2003), and undergraduate withdrawal (Harrison, 2006; MacKie, 2001), little discussion has addressed the undergraduate students' sense of place on campus. To such a gap, this paper explores the development of sense of place amongst undergraduate students in USM.

\section{LITERATURE REVIEW}

For decades, scholars from a kind of disciplines have tried to explore people's emotional relationships with place. Plethora of concepts are used to name the relationship between people and place in the literature such as "sense of place", "place attachment (PA)", "place identity (PI)" and "place dependence (PD)". Jorgensen and Stedman (2001, 2006) and Qian et al. (Qian \& Zhu, 2014; Qian, Zhu, \& Liu, 2011) argue that place attachment, place identity and some other related terms are parallel dimension which are under a supra-ordered concept: sense of place, which "is often invoked as the concept that best describes the relationship between people and their spatial-environmental settings" (NielsenPincus, Hall, Force, \& Wulfhorst, 2010, p. 443).

In his foundation book: The Sense of Place, Steele defines sense of place as "the pattern of reactions that a setting stimulates for a person. These reactions are a product of both features of the setting and aspects the person brings to it" (Steele, 1981, p. 12). Tuan argues that "visual perception, touch, movement, and thought combine to give us our characteristic sense of place" (Tuan, 1979, p. 390).

Place dependence refers to people's functional reliance on the amenities and resources that places provide. Jorgensen and Stedman (2001) point out that "place dependence concerns how well a setting serves goal achievement given an existing range of alternatives" (p. 234). 
Place attachment refers to the emotional bonds people develop with places. It "is the emotional link formed by an individual to a physical site that has been given meaning through interaction" (Milligan, 1998 , p. 2). It "involves an interplay of affect and emotions, knowledge and beliefs, and behaviors and actions in reference to a place" (Altman \& Low, 1992, p. 5).

In the seminal paper: The City and Self-Identity, Proshansky (1978) defines place identity as "those dimensions of self that define the individual's personal identity in relation to the physical environment by means of a complex pattern of conscious and unconscious ideas, beliefs, preferences, feelings, values, goals, and behavioral tendencies and skills relevant to this environment" (p. 155).

Jorgensen and Stedman (2001) explore the foundation of sense of place with three dimensions (place attachment, place identity and place dependence) equating with component of attitudes (affect, cognition, and conation). "Place attachment is equated with the affective (or emotional) component of attitude; place identity as the cognitive domain whereby a place is part of the social actor's sense of self; and, place dependence represents the conative domain of attitude in which the dependence expressed for one's setting is relative to the behaviors performed there" (p. 237).

Scholars point out that the people and place have to be put in a specific context if he want to deeply comprehend and present the people-place relationships. In this paper, the research objective is to investigate the undergraduate students' sense of place to the campus of USM.

\section{RESEARCH METHODS}

\subsection{Place of fieldwork}

Established as the second university in Malaysia in 1969, USM is a Research Intensive University recognized by the Ministry of Higher Education Malaysia in 2007. In 2008, USM became the first university in Malaysia selected by the Malaysian government to participate in the Accelerated Programme for Excellence (APEX), a fast-track programme that helps tertiary institutions achieve world-class status. The main campus of USM across a land area of 240.13 hectares. It has a total of 25 blocks of in-campus accommodation, 18 cafeterias, 29 halls, 16 schools, 3 libraries, 8 sport facilities, a mosque, and a museum (Ler \& Zainon, 2014). Malays, Chinese, Indian and many other ethnic groups live together in Malaysia which are the main source of students in USM. There are also a large number of international students from more than 20 countries in USM.

\subsection{Participants}

A sample of 114 undergraduate students was selected randomly from freshman to senior in USM. The questionnaire comprised 5 main sections:

\subsection{Measures}

Section A: A demographic information needed to be filled out by the participants, including the information on gender, age, race, nationality, major, school, study level and accommodation.

Secton B: The construct of place dependence is measured by two components: the quality of the current place to satisfy goal directed in terms of facilities for entertanment, study, and sports, and the cultural and academic activies; and how it compares to other universities.

Section C: The construct of place attachment relates to behavioral commitment and emotional bonding with four items that are widely used in the related studies.

Section D: The construct of place identity refers to 4 items to reflect personal position in place and self-identity on campus.

The quesitions employ five-point Likert-scale with 1 denoting "strongly disagress" and 5 denoting "strongly agree". SPSS 18.0 was used to test various statistical performance.

\section{ANALYSIS AND RESULTS}

Descriptive statistics for all demographic information are presented in Table 1.

Table 1. Demographic information.

\begin{tabular}{|l|l|l|l|}
\hline Demographic & Variables & Frequencies & Percentage \\
\hline Gender & Male & 49 & 43.0 \\
\cline { 2 - 4 } & Female & 65 & 57.0 \\
\hline Age & Under 20 & 13 & 11.4 \\
\cline { 2 - 4 } & $20-23$ & 87 & 76.3 \\
\cline { 2 - 4 } & $24-26$ & 11 & 9.6 \\
\cline { 2 - 4 } & $27-29$ & 1 & 0.9 \\
\cline { 2 - 4 } & Above 30 & 2 & 1.8 \\
\hline Race & Malay & 29 & 25.4 \\
\cline { 2 - 4 } & Chinese & 61 & 53.5 \\
\cline { 2 - 4 } & Indians & 8 & 7.0 \\
\cline { 2 - 4 } & others & 16 & 14.0 \\
\hline \multirow{5}{*}{ Nationality } & Malaysia & 78 & 68.4 \\
\cline { 2 - 4 } & International & 36 & 31.6 \\
\hline
\end{tabular}

The reliability tests are conducted for the three constructs of sense of place (Table 2). The results shows a reliability coefficient from 0.832 to 0.869 , suggesting evidence for the internal consistency of the items. 
Table 2. Cronbach's alpha for three constructs of sense of place in the questionnaire.

\begin{tabular}{|l|l|}
\hline Construct & Cronbach's Alpha \\
\hline Place Dependence & 0.832 \\
\hline Place Attachment & 0.843 \\
\hline Place Identity & 0.869 \\
\hline
\end{tabular}

Scores for each of the three construct of sense of place (place dependence, place attachment and place identity) are not evenly distributed (Table 3). For all the three construct, the largest groups fall into the category of 3 4, which can be concluded that most of undergraduate students' psychological bonding with place is at a moderate level. The respondents who reported weak feelings (1 2 and 2 3) are fewer, around 10 per cent, while repspondents who have extremely intense place bonding are in a medium number. The mean scores for the three constructs are slightly beyond or close to 3.7 . Therefore, it can be conclued that the respondents have developed dependence on, attachment to and identification with USM campus. The data shows that the mean socre of place identity is slightly lower than the mean socres of place dependence and place dependence.

Table 3. Distribution of scores for each construct.

\begin{tabular}{|c|c|c|c|c|c|c|}
\hline & \multicolumn{2}{|c|}{ PD } & \multicolumn{2}{c|}{ PA } & \multicolumn{2}{c|}{ PI } \\
\hline & Freq. & Perc. & Freq. & Perc. & Freq. & Perc. \\
\hline $1 \sim 2$ & 3 & 2.63 & 3 & 2.63 & 2 & 1.75 \\
\hline $2 \sim 3$ & 6 & 5.26 & 11 & 9.65 & 19 & 16.67 \\
\hline $3 \sim 4$ & 72 & 63.16 & 58 & 50.88 & 74 & 64.91 \\
\hline $4 \sim 5$ & 33 & 28.95 & 42 & 36.84 & 19 & 16.67 \\
\hline Mean & 3.7937 & & 3.8925 & & 3.6908 & \\
\hline S.D & 0.5884 & & 0.7233 & & 0.6452 & \\
\hline
\end{tabular}

To test whether the means of international and local students differ significantly on the three constructs of sense of place, the one-way between subjects analysis of variance (ANOVA) is used. The results are presented in Table 4 and Table 5.

Table 4. Descriptive on international and local students' place dependence, place attachment and place identity.

\begin{tabular}{|l|l|l|l|l|}
\hline & & $\mathrm{N}$ & Mean & S.D \\
\hline \multirow{3}{*}{ PD } & Malayisa & 78 & 3.8494 & 0.5262 \\
\cline { 2 - 5 } & International & 36 & 3.6736 & 0.6978 \\
\hline \multirow{2}{*}{ PA } & Malayisa & 78 & 3.9744 & 0.6904 \\
\cline { 2 - 5 } & International & 36 & 3.7153 & 0.7703 \\
\hline \multirow{2}{*}{ PI } & Malayisa & 78 & 3.8077 & 0.5879 \\
\cline { 2 - 5 } & International & 36 & 3.4375 & 0.6979 \\
\hline
\end{tabular}

There were not significant difference on students' place dependence and place attachment on campus between international and local students $(p>.05)$.
The international and local students' place identity varied significantly, $F(1,112)=8.659, p<.05, \eta^{2}$ $=.0718$. The score of local students' place identity $(M=3.8077, S D=.5879)$ showed significantly higher than the international students' place identity $(M=3.4375, S D=.6979)$.

Table 5. The result for the one-way between subjects ANOVA.

\begin{tabular}{|l|l|l|l|l|l|l|}
\hline \multirow{4}{*}{ PD } & & SS & df & MS & F & Sig. \\
\cline { 2 - 7 } & Betw. Groups & .761 & 1 & .761 & 2.221 & .139 \\
\hline & Within Groups & 38.364 & 112 & .343 & & \\
\cline { 2 - 8 } & Total & 39.124 & 113 & & & \\
\hline \multirow{4}{*}{ PA } & Betw. Groups & 1.653 & 1 & 1.653 & 3.222 & .075 \\
\cline { 2 - 8 } & Within Groups & 57.468 & 112 & .513 & & \\
\cline { 2 - 8 } & Total & 59.121 & 113 & & & \\
\hline \multirow{3}{*}{ PI } & Betw.Groups & 3.376 & 1 & 3.376 & 8.659 & .004 \\
\cline { 2 - 8 } & Within Groups & 43.662 & 112 & .390 & & \\
\cline { 2 - 7 } & Total & 47.038 & 113 & & & \\
\hline
\end{tabular}

ANOVA is also used to test whether the means of Malay, Chinese, Indian and other races differ significantly on place dependence, place attachment and place identity (Table 6 and Table 7).

Table 6. Descriptive on the three construct of sense of place of students with different races.

\begin{tabular}{|l|l|l|l|l|}
\hline & & $\mathrm{N}$ & Mean & SD \\
\hline \multirow{4}{*}{ PD } & Malay & 29 & 4.0560 & 0.4612 \\
\cline { 2 - 5 } & Chinese & 61 & 3.7582 & 0.5092 \\
\cline { 2 - 5 } & Indian & 8 & 3.9063 & 0.6435 \\
\cline { 2 - 5 } & Others & 16 & 3.3984 & 0.8180 \\
\hline PA & Malay & 29 & 4.3017 & 0.6101 \\
\cline { 2 - 5 } & Chinese & 61 & 3.8074 & 0.6868 \\
\cline { 2 - 5 } & Indian & 8 & 3.7188 & 0.8066 \\
\cline { 2 - 5 } & Others & 16 & 3.5625 & 0.7555 \\
\hline PI & Malay & 29 & 4.0431 & 0.5472 \\
\cline { 2 - 5 } & Chinese & 61 & 3.5779 & 0.5783 \\
\cline { 2 - 5 } & Indian & 8 & 3.6563 & 0.9814 \\
\cline { 2 - 5 } & Others & 16 & 3.5000 & 0.6770 \\
\hline
\end{tabular}

The students' place dependence, place attachment and place identity varied significantly by their races, $F_{P D}(3,110)=4.974, p<.05, \eta^{2}=.1195, F_{P A}(3,110)$ $=5.151, p<.05, \eta^{2}=.1232, F_{P I}(3,110)=4.331, p$ $<.05, \eta^{2}=.1056$.

Tukey's post hoc procedure indicated that the score of Malay's place dependence on campus $(M=$ $4.0560, S D=.4612$ ) was significantly higher than the other racial place dependence $(M=3.3984, S D$ $=.8180)$. The score of Malay's place attachment to campus $(\mathrm{M}=4.3017, \mathrm{SD}=.6101)$ was significantly higher than the Chinese place attachment ( $\mathrm{M}=$ $3.8074, \mathrm{SD}=.6868$ ), and significantly higher than other raical place attachment $(\mathrm{M}=3.5625$, $\mathrm{SD}$ 
$=.7555)$. The score of Malay's place identity with campus $(\mathrm{M}=4.0431, \mathrm{SD}=.5472)$ was significantly higher than the Chinese place identity $(\mathrm{M}=3.5779$, $\mathrm{SD}=.5283)$, and significantly higher than other raical place identity $(\mathrm{M}=3.5000, \mathrm{SD}=.6770)$.

Table 7. Results for ANOVA and Post Hoc Tests.

\begin{tabular}{|l|l|l|l|l|l|l|l|}
\hline & & SS & df & MS & F & Sig. & Post Hoc \\
\hline \multirow{4}{*}{ PD } & Betw. & 4.67 & 3 & 1.56 & 4.974 & 0.003 & A > D \\
\hline & With. & 34.45 & 110 & 0.31 & & & \\
\cline { 2 - 8 } & Total & 39.12 & 113 & & & & \\
\hline \multirow{3}{*}{ PA } & Betw. & 7.28 & 3 & 2.43 & 5.151 & 0.002 & A > B \\
\hline & With. & 51.84 & 110 & 0.47 & & & A > D \\
\cline { 2 - 8 } & Total & 59.12 & 113 & & & & \\
\hline \multirow{2}{*}{ PI } & Betw. & 4.97 & 3 & 1.66 & 4.331 & 0.006 & A > B \\
\cline { 2 - 8 } & With. & 42.07 & 110 & 0.38 & & & A > D \\
\cline { 2 - 8 } & Total & 47.04 & 113 & & & & \\
\hline
\end{tabular}

\section{CONCLUSION}

The result illustrated that the underguraduate students in USM showed relatively strong sense of place to the campus. Place identity gets relatively lower score in this study, which coincides with the prevous research (Jorgensen \& Stedman, 2001; Qian et al., 2011). Place identity also shows significant difference between international students and local students. It correspoonds to the discussion that people may dependent on or attach to a place, but it may take more than liking or attachment to incorporate the place as part of one's self (Lewicka, 2008). Based on the result in this study and the definition of place identity in literature review, as "phyical world sociallization of the self" (Proshansky, Fabian, \& Kaminoff, 1983, p. 57), we may conclude that place identity may show a higher hierarchy of people-place relathionship than place dependence and place attachment. This hypothesis needs to be test in the future research.

\section{REFERENCES}

[1] Altman, I., \& Low, S. M. (1992). Place Attachment: A Conceptual Inquiry. In I. Altman \& S. M. Low (Eds.), Place Attachment (Vol. 12, pp. 1-12). New York: Plenum Press.

[2] Amole, D. (2009). Residential satisfaction in students' housing. Journal of Environmental Psychology, 29(1), 7685. doi: http://dx.doi.org/10.1016/j.jenvp.2008.05.006

[3] Chow, K., \& Healey, M. (2008). Place attachment and place identity: First-year undergraduates making the transition from home to university. Journal of Environmental Psychology, 28(4), 362-372.

[4] Harrison, N. (2006). The impact of negative experiences, dissatisfaction and attachment on first year undergraduate withdrawal. Journal of Further and Higher Education, 30(4), 377-391. doi: 10.1080/03098770600965383

[5] Jorgensen, B. S., \& Stedman, R. C. (2001). Sense of Place as an Attitude: Lakeshore Owners Attitudes toward Their Properties. Journal of Environmental Psychology, 21(3), 233-248.

[6] Jorgensen, B. S., \& Stedman, R. C. (2006). A comparative analysis of predictors of sense of place dimensions: Attachment to, dependence on, and identification with lakeshore properties. Journal of Environmental Management, $\quad 79(3), \quad 316-327 . \quad$ doi: http://dx.doi.org/10.1016/j.jenvman.2005.08.003

[7] Khozaei, F., Hassan, A. S., \& Khozaei, Z. (2010). Undergraduate Students' Satisfaction with Hostel and Sense of Attachment to Place: Case Study of University Sains Malaysia. American Journal of Engineering and Applied Sciences, 3(3), 516-520.

[8] Ler, S., \& Zainon, W. (2014). Campus Mobile Navigation System Based on Shortest-Path Algorithm and Users Collaborations. In H. Y. Jeong, M. S. Obaidat, N. Y. Yen \& J. J. Park (Eds.), Advances in Computer Science and its Applications (Vol. 279, pp. 791-797): Springer Berlin Heidelberg.

[9] Lewicka, M. (2008). Place attachment, place identity, and place memory: Restoring the forgotten city past. Journal of Environmental Psychology, 28(3), 209-231.

[10] Lowe, H., \& Cook, A. (2003). Mind the Gap: Are students prepared for higher education? Journal of Further and Higher Education, 27(1), 53-76. doi: $10.1080 / 03098770305629$

[11] MacKie, S. E. (2001). Jumping the Hurdles Undergraduate Student Withdrawal Behaviour. Innovations in Education and Teaching International, 38(3), 265-276. doi: 10.1080/14703290110056371

[12] Milligan, M. J. (1998). Interactional Past and Potential: The Social Construction of Place Attachment. Symbolic Interaction, 21(1), 1-33. doi: 10.1525/si.1998.21.1.1

[13] Nielsen-Pincus, M., Hall, T., Force, J. E., \& Wulfhorst, J. D. (2010). Sociodemographic effects on place bonding. Journal of Environmental Psychology, 30(4), 443-454.

[14] Proshansky, H. M. (1978). The City and Self-Identity. Environment and Behavior, 10(2), 147-169. doi: 10.1177/0013916578102002

[15] Proshansky, H. M., Fabian, A. K., \& Kaminoff, R. (1983). Place-identity: Physical world socialization of the self. Journal of Environmental Psychology, 3(1), 57-83. doi: 10.1016/S0272-4944(83)80021-8

[16] Qian, J., \& Zhu, H. (2014). Chinese urban migrants' sense of place: Emotional attachment, identity formation, and place dependence in the city and community of Guangzhou. Asia Pacific Viewpoint, 55(1), 81-101. doi: 10.1111/apv.12039

[17] Qian, J., Zhu, H., \& Liu, Y. (2011). Investigating urban migrants' sense of place through a multi-scalar perspective. Journal of Environmental Psychology, 31(2), 170-183.

[18] Steele, F. (1981). The Sense of Place. Boston, Massachusetts: CBI Publishing Company, Inc.

[19] Tuan, Y.-F. (1974). Space and Place: Humanistic perspective. Progress in Geogrphical, 6, 233-246.

[20] Tuan, Y.-F. (1979). Space and Place: Humanistic Perspective. In S. Gale \& G. Olsson (Eds.), Philosophy in Geography (pp. 387-427). 